\title{
Promoting inclusion in school libraries
}

\author{
Glória Bastos \\ Universidade Aberta / CEMRI \\ Rua da Escola Politécnica, 147 1269-001 Lisbon \\ Portugal \\ gloria.bastos@uab.pt
}

\begin{abstract}
Several international documents explicitly point out the responsibility of libraries in supporting people with special needs, actively promoting social inclusion processes. In the school context, one of the challenges lies precisely on its ability to achieve that all students, regardless their differences and their specific needs, are able to succeed in their learning. In Portugal, the integration of students with special educational needs in regular schools brought new challenges to school libraries. In this paper we present some insights from some projects held in the SL. The results of these studies show that in general both teachers librarians and special educators are little aware of the important role that the school library can play with these students and that a collaborative work with the teacher librarian have positive impacts, both in increasing the self-esteem of students and developing their reading and information literacy skills.
\end{abstract}

Keywords: School libraries, Students with special needs, Reading promotion, Information literacy, collaboration

\section{Introduction}

The issues connected to inclusive education are a central concern for different European organizations. In more recent years, these organizations have also been engaged in a broader definition of inclusive education, like the one proposed at the 48th Session of the International Conference on Education (ICE) (2008): "inclusive education is an on-going process aimed at offering quality education for all while respecting diversity and the different needs and abilities, characteristics and learning expectations of the students and communities, eliminating all forms of discrimination". The Strategic Objective 3 of the strategic framework for European co-operation in education and training (ET 2020) Promoting equity, social cohesion and citizenship - also states: "Education and training systems should aim to ensure that all learners - including those from disadvantaged backgrounds, those with special needs and migrants - complete their education, including, where appropriate, through second-chance education and the provision of more personalised learning".

In the context of children with disabilities we must underline the importance of the UNESCO Salamanca Statement (1994). The statement proposes a "Framework for Action" with the guiding principle that ordinary schools should accommodate all children, regardless of their physical, intellectual, social, emotional, linguistic or other conditions. All educational policies, 
says the Framework, should stipulate that disabled children attend the neighbourhood school "that would be attended if the child did not have a disability" (p. 17) as "inclusive schooling is the most effective means for building solidarity between children with special needs and their peers" (p. 12). Special education aims to ensure educational and social inclusion, access and educational success, autonomy, emotional stability, and the promotion of equal opportunities, preparation for further study or for proper preparation for professional life and a transition from school to employment of children and young people with permanent special educational needs (SEN).

In the specific context of libraries, we also find several international documents, such as the Manifesto of School Libraries of the International Federation of Library Associations - IFLA / UNESCO (1999) ) or the declaration of Alexandria for the information society (2005) that explicitly point out the responsibility of libraries in supporting people with special needs, actively promoting social inclusion processes. In the school context, one of the challenges lies precisely on its ability to achieve that all students, regardless of their differences and their specific needs, are able to succeed in their learning.

\section{School libraries and inclusion: Portuguese context}

Portugal is one of the countries that adopted the Salamanca Statement but since 1986, the organization of the Portuguese Educational System (Law n. ${ }^{\circ} 46 / 86,14$ th October) already stipulated the integration of students with SEN in regular classes although schools sometimes continued refusing these students until the beginning of the nineties. In 1991 a specific law was published (Law n. ${ }^{\circ} 319 / 91,23$ rd August), stipulating the conditions that schools should benefit to integrate those students. The most recent law, published in 2008 (Law n. ${ }^{\circ} 3 / 2008,7$ th January), has improved some of the former orientations, stressing the principles of equity and success for all students. This law is a framing for educational responses that can be developed within the adequacy of the educational process for students with SEN, and places at the centre of the educational intervention the Individualized Education Plan, a document that describes how the school will meet the child's educational needs at no cost to the family.

The integration of students with special needs or disabilities in regular schools brought new challenges to school libraries. Due to the work done in the last decade, under the orientation of the Portuguese School Libraries Network, the School Library is now seen as an important educational value, to support curriculum activities and leisure. In this sense, one of its lines of action should be directed to students with special educational needs, namely helping the collaborative work among the teacher librarian, classroom teachers and special educators, contributing to the development of these children and helping them to achieve educational success. But as we will see, this has not been a practice in Portugal, as it seems to be also a problematic area in other countries (e.g. Farmer, 2009; Myhill et al, 2012).

At this moment, three documents serve as guides for the work in Portuguese School Libraries and our first step is to examine how these documents refer to special education. The first document, published in 1996 (Launching the School Library Network), is the foundational text for SL, stating the principles and the guidelines for the work in the field, and 
announcing the creation of the School Libraries Network in Portugal. In this document, we only find some recommendations concerning accommodation and access to equipment and resources for students with disabilities (p. 44, p. 178). The evaluation model for school libraries $(2010 ; 2013)$ and the guidelines Learning with the school library (2012) present the more recent and strategic principles and procedures for Portuguese School Libraries.

In the Evaluation Model (2010) it is explicitly mentioned the necessary articulation between the SL and Special Needs Educators (p. 18, p. 19) in the domain A - "Support to the curriculum". Effective collaboration requires that both parties contribute to the effort and in these pages the responsibility and initiative of the Teacher Librarian is clearly described in the following "factors for SL success" (p.18):

- The SL works with Special Educational Needs Service aiming to support the work plans of Special Educators

- The SL collaborates with teachers responsible for educational support activities, by helping them to implement the strategies defined for every student .

- The SL is used by special educators and teachers responsible for educational support activities in collaboration with the teacher librarian or in an autonomous way.

The model also includes some suggestions for improvement in this particular issue (p. 19):

- To promote planning meetings with teachers working on Special Educational Services.

- To organize training sessions on the SL for Special Educators and other teachers working in Educational support services.

- To improve communication between the SL and those teachers in order to achieve their resources needs.

- To suggest to those teachers ways for collaborative work concerning different learning activities.

In the recent revision of the model (2013) there is also a mention (p. 44) but this time the reference is integrated in the domain D - "School Library Management": "The SL works with Special Educational Services, enriching Special Education planning and improving students learning outputs" (p. 44).

Considering the lack of collaborative work that still exists between Teacher Librarians and Special Needs Educators, we think that this change to a "soft" compromise of the TL also shifts the main focus of the TL work (from curriculum support to a management issue) and can contribute for a continuous minimization of collaborative values.

The referential Learning with the School Library (2012) that presents guidelines and examples of activities in three areas - Reading Literacy, Media Literacy and Information Literacy - has no particular allusion to students with special needs. For instance, there are several examples of activities with a focus on different curricular areas, but with no mentions to the possible articulation with special education or to a probable adaptation for students 
with SEN. This absence can contribute to keep those students outside the SL, not beneficiating from the important contributions that the SL can bring to their education and to their integration in society, considering the vital importance of the mentioned topics in today's world. Taking into account that there is, in general, little collaborative work among the Teacher Librarian and other teachers in the school (e.g. Bastos, 2012) and specifically between TL and special needs educators (e.g. Pinheiro, 2014), this referential should have mentioned in an explicit way the relation with students with special needs. This situation reminds us Farmer words: "Since library use should support the curriculum, school library media specialists can link learning activities with special educators' strategies. Even more than special educators, school library media specialists work with the entire school community, and can introduce special educators to teachers who might not otherwise come into contact with them" $(2009$, p. 41$)$.

A final word to the School Libraries Network Strategic Framework for 2014-2020 (2013). This document defines priority areas and lines for intervention that will guide School libraries action contributing to Portuguese educational objectives for this period. The framework identifies thirteen action lines, and number 12, "SL as inclusive organizations, guaranteeing equal access to information services and resources" (p. 22), points out that "School Libraries are, by their nature and mission, a natural support base for pupils with special educational needs" and that they must create "physical and technological conditions that make libraries able to give different answers to students with special educational needs".

Several studies underline the difficulties that Portuguese schools continue to face as students with various disabilities are integrated in regular classes (and we are that schools in other countries have similar problems). So, it is important to diversify the approaches and at the same time to congregate efforts in the school to improve the educational, personal and social success of these students. In this context, international studies and also some research developed in Portugal show that the school library has a relevant role to play supporting children with SEN. After establishing the framework for Portuguese school libraries intervention concerning students with special educational needs, we intend to present some results from research held in Portuguese schools and projects that are now being developed .

\section{Insights from the research}

As Farmer underlines, "School library media specialists have a broad and deep knowledge about resources across the curriculum and in different formats, which can help special educators match materials with individual students. While special educators might know more about adaptive technologies, school library media specialists are likely to know Internet and other online resources that could be useful for students with special needs" (2009, p. 40).

Taking into account this situation, and considering that the dissemination of good practices is an important way for improving the context that we examine in this paper, in the next paragraphs we will report some results from studies that focus on the relationship between teacher librarians and special needs students in Portuguese Schools. Until this moment, there is little research specifically in the above mentioned topic. In Portuguese academic repositories research we have find just four master thesis (Moreira, 2003; Pires, 2013; 
Oliveira 2011 and Pinheiro, 2014). The last two are research works done at my University (Universidade Aberta/Open University) and another one is in progress. Those studies have developed different approaches so the findings focus on different aspects according to their goals and evidence collected.

For this analysis I will retain the results of the research studies developed in Universidade Aberta, in the context of a master degree in School Librarianship.

In examining ways to help students with literacy, Oliveira developed an intervention plan with one student with SEN (sixth-grade) and collaborative work with the special educator. She had also interviewed 9 special educators working in the same school aiming to identify what they thought about the role of the SL towards students with special needs and their experience in collaborative work with the teacher librarian. The results with the intervention plan show that the student (with communication and language problems and a previous personal story of educational failures and a significant lack of self-esteem) had a substantial progress in all curricular subjects and also concerning social integration with peers. The areas supervised in a closely way by the TL - reading and information literacy skills - were particularly improved. The interview with the student's mother confirmed the improvements identified, with special emphasis on the social dimension (a particular concern for the family). It is important to underline that all the activities supervised by the TL had a strong connection with the student's work either done in an autonomous way or integrated in the regular class with other classmates, confirming that "the excitement for students is learning centered in solving a problem or addressing an issue they find meaningful" (Taylor, 2006, p.105).

Concerning the results of the interviews with the group of special education teachers, all the teachers had recognized the opportunities that the SL can offer to students with SEN. Nevertheless, they don't usually integrate SL resources in their work plans. In this sense, the example of the success of the partnership develop with one of the special educators had also a positive impact on the special education teachers group, by increasing opportunities for further collaborative work.

Pinheiro also examined the perceptions of special needs educators about the SL and their experiences in collaborative work with the teacher librarians. He surveyed 59 special educators and 6 Teacher Librarians from 6 groups of schools in a district in the north of Portugal. The findings were similar to the ones presented by Oliveira. In fact, all the teachers recognized the educational value of the $S L$ and the collaborative work with the Teacher Librarian, but only a few usually go to the library or try to articulate with the TL. The most successful example was based in a SL team that integrated a special educator and it showed to be a good practice. Not only the SL had more and better resources to support students with special educational needs but the collaborative work among the TL and special educational teachers was also more visible, contributing to impact student achievement.

The study that is still in progress, done by a master student under my supervision, focus on the implementation of a recent project launched in 2012-2013 by the Portuguese School Libraries Network with the support of the National Reading Plan and other public and private organizations. The project is entitled "We can read all together" ("Todos juntos podemos ler") and its main goal is to improve reading competences and habits among all students including those with special educational needs. The project intends to equip school libraries 
with adequate resources in different formats accessible to students with SEN and to develop good practice in promoting reading, taking into account the students individual capabilities and needs. School Libraries that participate in the project receive extra funds so that they can acquire special resources and technological equipment: eBooks, Daisy (Digital Accessible Information System), Braille, audiobooks, LGP (Portuguese Sign Language), Pictographic Symbols for Communication, eBook/ EPUB (electronic publication format) and 3D Draws. With this equipment they became more inclusive spaces and can help students in a more effective way.

Nowadays, the fundamental principle of an inclusive school is that all children should learn together, where possible, and that ordinary schools must recognize and respond to the diverse needs of their students, while also having a continuum of support and services to match these needs. It is important, for example, to diversify technological resources and their use as a way for the improvement of inclusion, namely helping children with SEN to be more autonomous and develop their learning process. The reports ICTs in Education for People with Disabilities - Review of Innovative Practice (2011) and Raising Achievement for All Learners - Quality in Inclusive Education for People with Disabilities (2012) highlight the importance of ICT in supporting access to the curriculum and personalized learning. In this particular point, the project "We can read all together" is an important contribution as it enables school libraries to strengthen their technological resources.

The project is focused on reading but other competences are also improved when students participate in activities. School libraries involved in the project display the activities organized through their blogs and other web dispositive, and in fact we can sate that a great effort is being done to put "all together" in the school library.

\section{Final remarks}

In Portugal there is still little research on the relationship between SL and special education so focused studies on this topic and dissemination of good practices thus appear as essential for the development and consolidation of the work that can be done by teacher librarians. The results of the research studies examined show that in general both teachers librarians and special educators are little aware of the important role that the school library can play with these students and that a collaborative work with the teacher librarian have positive impacts, both in increasing the self-esteem of students and developing their reading and information literacy skills.

In their recent work on inclusive pedagogy, Florian and Black-Hawkins (2011) explored the idea that we need a shift in focus from "additional needs" to learning for all, and the last project we have mentioned is trying to meet this aim. Another idea is that all teachers have to respect the dignity of learners as full members of the classroom community. Nevertheless, many school libraries don't have the necessary resources yet to conveniently support all learners. For example, at this moment in a universe of several thousands of groups of schools with a SL integrated in the Portuguese Network of School Libraries, only 20 groups of schools have the possibility of participating in the project "We can read all together" and benefit from specific resources for students with SEN. 
So, in most part of schools teacher librarians and special educators say what the research studies examined concluded: that besides the lack of collaborative work there is also a lack of adequate resources and specialized training concerning the needs of children with disabilities. As Allen (2008) has also reported, a majority of teacher librarians identified an insufficiency in their knowledge in the area of special education. Another problem is the number of students per class and also the high number of students that each TL should support. These are still barriers for an effectively inclusion of students with SEN. Even if everybody is convicted about the benefices obtained with the presence of those students in regular classes and in the school library, in fact the reality shows us a diverse picture. But we believe that small steps can bring major achievements.

\section{References}

Allen, Kendra (2008). The School Library Media Program and Special Education Programs. MS Thesis. University of North Carolina at Chapel Hill, Chapel Hill, NC.

http://ils.unc.edu/MSpapers/3451.pdf

Bastos, Glória (2012). Collaboration or parallel worlds? Information literacy practices in Portuguese school libraries. Proceedings of European Conference on Reading: Literacy and Diversity. Mons: IDEC, 23-28.

Conde, Elsa; Martins, Rosa \& Bastos, Glória (coord.) (2011). Modelo de avaliação da biblioteca escolar [2010-2013] [Evaluation Model for the School Library]. Lisboa: Rede de Bibliotecas Escolares - Ministério da Educação.

Conde, Elsa; Martins, Rosa \& Ochôa, Paula (coord.) (2013). Modelo de avaliação da biblioteca escolar 2014-2017 [Evaluation Model for the School Library]. Lisboa: Rede de Bibliotecas Escolares - Ministério da Educação

European Agency for Development in Special Needs Education (2009). Multicultural Diversity and Special Needs Education. Odense, Denmark: European Agency for Development in Special Needs Education

European Agency for Development in Special Needs Education (2012). Raising Achievement for All Learners - Quality in Inclusive Education. Odense, Denmark: European Agency for Development in Special Needs Education

Farmer, Lesley (2009). School Library Media Specialist Collaboration with Special Education Personnel in Support of Student Learning. Evidence Based Library and Information Practice, $4: 2,37-55$.

Florian, L. \& Black-Hawkins, K. (2011). Exploring Inclusive Pedagogy. British Educational Research Journal, 37(5), 813-828.

Myhill et al. (2012). Developing the capacity of teacher-librarians to meet the diverse needs of all schoolchildren:Project ENABLE. Journal of Research in Special Educational Needs, . 12(4), 201-216. 
Rede de Bibliotecas Escolares (2012). Aprender com a biblioteca escolar [Learning with the School Library]. Lisboa: Rede de Bibliotecas Escolares - Ministério da Educação.

Rede de Bibliotecas Escolares (2013). Programa Rede de Bibliotecas Escolares. Quadro estratégico: 2014-2020 [School Libraries Network. Strategic Framework: 2014-2020].

Lisboa: Rede de Bibliotecas Escolares - Ministério da Educação.

Taylor, Joie (2006).Information Literacy and the School Media Center. London: Libraries Unlimited.

UNESCO Institute for Information Technologies in Education and European Agency for Development in Special Needs Education (2011). ICTs in Education for People with Disabilities - Review of Innovative Practice. UNESCO IITE

UNESCO-IBE (2008). Conclusions and Recommendations of the 48th Session of the International Conference on Education (ED/BIE/CONFINTED 48/5). Geneva; UNESCO IBE.

UNESCO (1994) The Salamanca statement and framework for action on special needs education. Retrieved april, 2014, from http://www.unesco.org/education/pdf/SALAMA E.PDF

United Nations (2006). Convention on the Rights of Persons with Disabilities. New York: United Nations. Retrieved april 2014, from

http://dc.lib.unc.edu/cdm/ref/collection/s_papers/id/1117

\section{Biographical note}

Glória Bastos - Professor at the Department of Education and Distance Learning, Universidade Aberta (Portuguese Open University), where she teaches Children's Literature and coordinates the first master for teacher-librarians. Member of CEMRI - Research Centre for the study of Migrations and Intercultural Relations. The areas of interest are children's literature and school libraries. She has a PhD at Portuguese Studies and has presented sessions and published several books and articles in particular about children's literature, reading promotion and school libraries. She collaborates with several institutions on Teacher Training and in reading and children's literature programs. 